\title{
Penerapan Metode Pembelajaran Kolaboratif untuk Meningkatkan Aktivitas dan Hasil Belajar Siswa pada Materi Koloid Kelas XI IPA 1 SMA Negeri 3 Watampone
}

\author{
The Implementation of Collaborative Learning Methods to Increase Student \\ Learning Acitivity and Result Activity in Colloid Matter on XI IPA 1 Class \\ SMA Negeri 3 Watampone
}

\author{
Sitti Nurpaidah \\ SMA Negeri 3 Watampone, Kabupaten Bone \\ Email: chaculenurpaidah@gmail.com
}

\begin{abstract}
ABSTRAK
Penelitian ini bertujuan untuk mengetahui adanya peningkatan keaktifan siswa dan hasil belajar siswa sebelum dan setelah penerapan metode pembelajaran kolaboratif untuk meningkatkan hasil belajar siswa kelas XI IPA 1 SMA Negeri 3 Watampone. Penelitian ini dilaksanakan sebanyak 2 siklus dan setiap siklus dilakukan sebanyak empat kali pertemuan termasuk tes setiap akhir siklus. Pengumpulan data dilakukan dengan teknik Observasi terhadap aktifitas siswa dan aktifitas guru selama proses pembelajaran di kelas tersebut dan catatan lapangan selama tindakan pembelajaran berlangsung. Dalam penelitian ini terlihat jelas bagaimana siswa dalam melakukan kolaborasi pada pembelajaran berlangsung sehingga terlihat: (a) keaktifan siswa dalam mengerjakan LKS yang akan didiskusikan pada siklus I rata-rata mencapai 80,07\% dan pada siklus II ada peningkatan menjadi $83,33 \%$. (b) siswa yang aktif bekerja sama dengan kelompoknya rata-rata pada siklus I mencapai $78,97 \%$ dan pada siklus II mencapai $83,33 \%$, (c) siswa yang mampu mengajukan pertanyaan dan menjawabnya yang berhubungan dengan materi diskusi pada siklus I mencapai $11,00 \%$ dan $8,89 \%$, sedangkan pada siklus II mencapai $15,00 \%$ dan $11,66 \%$, (d) siswa yang kreatif dalam memberikan jawaban kepada kelompok yang bertanya pada siklus I mencapai $6,67 \%$, dan siklus II mencapai $8,33 \%$, (e) siswa yang disiplin dalam proses pembelajaran pada siklus I mencapai $80,07 \%$, dan pada siklus II mencapai 83,33\%. Pada analisis hasil belajar dengan menggunakan metode ini diperoleh data: (a) hasil tes belajar siswa pada siklus I dengan skor rata-rata 60,50, dan pada siklus II dengan skor ratarata 72,33. (b) pengkategorian tingkat ketuntasan belajar siswa yang memperoleh skor 70 keatas pada siklus I sebanyak 17 Orang (46,67\%), dan pada siklus II sebanyak 26 orang $(73,33 \%)$. Hasil penelitian ini menunjukan bahwa terjadi peningkatan keaktifan belajar siswa kelas XI IPA 1 SMA Negeri 3 Watampone setelah menerapkan pembelajaran dengan menggunakan metode kolaboratif.

Kata kunci: Pembelajaran kolaboratif, Hasil belajar
\end{abstract}

Jurnal Chemica Vol. I 8 Nomor 2 Desember 20I7, 30 - 42 


\begin{abstract}
This study aims to determine the increase of student activeness and student learning outcomes before and after the implementation of collaborative learning methods to improve student results class XI IPA 1 SMA Negeri 3 Watampone. This research was conducted in 2 cycles and each cycle was done four times meeting including test every end of cycle. Data collection is done by observation techniques on student activities and teacher activities during the learning process in the classroom and field notes during the learning action takes place. In this research, it can be seen how the students in doing the collaboration on the learning take place so that it can be seen (a) the activity of the students in doing the LKS that will be discussed in the cycle I average reached $80.07 \%$ and in the cycle II there is an increase to $83.33 \%$. (b) The students who actively cooperate with the group on average in the cycle I reached $78.97 \%$ and in the cycle II reached $83.33 \%$, (c) Students who are able to ask questions and answer it related to the discussion material in cycle I reached $11.00 \%$ and 8.89 $\%$, while in the cycle II reached $15.00 \%$ and $11.66 \%$. (d) Creative students in giving answer to the group that asks in the cycle I reached 6.67 $\%$ and cycle II reached $8.33 \%$, (e) Students who are disciplined in the learning process in the cycle I reached $80.07 \%$ and on cycle II reached $83.33 \%$. In the analysis of learning outcomes using this method obtained data: (a) the results of student learning tests on the first cycle with an average score of 60.50 and in cycle II with an average score of 72.33 , (b) Categorization of students level of completeness to get score 70 up on cycle I of 17 people $(46.67 \%)$ and in cycle II counted 26 people $(73.33 \%)$. The results of this study indicate that there is an increase in student teaching activity class XI IPA 1 SMA Negeri 3 Watampone after applying the learning by using collborative methods.
\end{abstract}

Keywords: Collborative methods, Learning results

\section{PENDAHULUAN}

Pembelajaran kolaboratif merupakan bagian dari pembelajaran yang menitik beratkan pada kerjasama antara siswa yang dilaksanakan oleh kelompok yang dibangun sendiri oleh anggota kelompok walaupun tugas/masalah berasal dari guru (Mulyawan, 2006). Proses belajar mengajar dengan menggunakan metode ini, para siswa yang memiliki tingkat akademik yang berbeda-beda diharapkan dapat mengemukakan permasalahan yang dihadapi dalam diskusi kelompok untuk dipecahkan bersama sementara tugas pengajar berperan sebagai fasilitator dan pembimbing.

Penerapan langkah-langkah pembelajaran kolaboratif memiliki kelebihan yang didapatkan oleh siswa, antara lain melatih rasa peduli, 
perhatian dan kerelaan untuk berbagi, mendorong siswa untuk menjadi pebelajar yang mandiri, dan bertanggungjawab terhadap kelompoknya, serta mengutamakan kepentingan kelompok diatas kepentingan pribadi. Adapun kekurangan yang memungkinkan muncul dalam pembelajaran kolaboratif adalah siswa yang lebih pintar akan merasa dirugikan apabila belum mengerti tujuan yang sesungguhnya dari proses ini dan siswa akan merasa keberatan dengan nilai yang peroleh ditentukan oleh prestasi atau pencapaian kelompoknya (Santyasa, 2006).

Berdasarkan informasi dari salah seorang guru mata pelajaran kimia di SMA Negeri 3 Watampone, masalah yang dihadapi dalam proses belajar mengajar khususnya pada mata pelajaran kimia adalah masih kurangnya daya serap siswa terhadap materi pelajaran kimia, hal ini ditunjukkan nilai rata-rata hasil belajar siswa kelas XI IPA adalah 6,0, sedangkan standar ketuntasan yang digunakan guru dalam penilaian adalah $\geq 70$ berarti tuntas dan $<70$ tidak tuntas. Faktor yang mempengaruhi daya serap siswa terhadap mata pelajaran kimia antara lain; inteligensi, kurangnya minat belajar, dan kondisi lingkungan. Strategi dan metode mengajar digunakan guru bersifat satu arah yaitu pembelajaran berpusat pada guru dan kurang melibatkan siswa dalam proses belajar mengajar.

Mata pelajaran kimia sebagian besar berhubungan dengan kehidupan sehari-hari diantaranya pada materi sistem koloid. Guru dalam menyampaikan pelajaran kepada siswa khususnya pada materi sistem koloid hendaknya selektif memilih metode sehingga siswa akan lebih mudah memahami materinya. Salah satu metode yang dapat membatu siswa melakukan kegiatan belajar mengajar dengan baik adalah pembelajaran kolaboratif, yang melibatkan seluruh siswa untuk menyumbangkan ide, saling tukar informasi berdasarkan pengetahuan yang dimiliki siswa. Materi sistem koloid sangat tepat untuk menerapkan metode pembelajaran kolaboratif dengan isi materinya berupa materi bacaan dan perlu informasi-informasi yang relevan dengan materi ini.

Penelitian ini bertujuan untuk memperoleh informasi mengenai penerapan langkah-langkah pembelajaran kolaboratif dalam peningkatan hasil belajar kimia siswa kelas XI IPA1 SMA Negeri 3 Watampone.

\section{METODE PENELITIAN}

adalah penelitian yang digunakan dengan tahapan pelaksanaan yang meliputi perencanaan, pelaksanaan tindakan, observasi dan evaluasi serta refleksi yang selanjutnya tahapantahapan tersebut dirangkaikan dalam satu siklus kegiatan. Subjek penelitian ini adalah siswa kelas XI IPA 1 pada semester genap tahun ajaran 2016/2017 dengan jumlah 30 orang yang terdiri dari 12 orang laki-laki dan 18 orang perempuan. Penelitian ini terdiri atas beberapa siklus tergantung 
ketercapaian tujuan penelitian pada siklus sebelumnya.

\section{A. Pelaksanaan Siklus I}

Kegiatan yang dilakukan dalam tahap perencanaan ini adalah sebagai berikut: 1) Peneliti bersama dengan guru mata pelajaran kimia melakukan diskusi untuk membahas permasalahan yang dapat dipecahkan dalam penelitian ini. 2) Menelaah materi mata pelajaran kimia kelas XI semester genap, 3) Menyusun perangkat pembelajaran, 4) Membuat dan menyusun alat evaluasi yang akan diberikan pada akhir siklus I, 5) Membuat lembar pedoman observasi tiap pertemuan untuk memantau kegiatan siswa selama proses pembelajaran dengan menentukan indikator yang ingin diamati perkembangannya.

Pembelajaran kolaboratif yang dilakukan pada tahap Tindakan adalah: 1) Membentuk beberapa kelompok yang beranggotakan 5-6 orang secara heterogen berdasarkan tingkat prestasinya, diperoleh dari hasil belajar siswa, 2) Setiap kelompok menetapkan tujuan belajar bersama dan membagi tugas masing-masing, 3) Semua siswa dalam kelompok membaca, menjawab LKS, berdiskusi, dan menulis berdasarkan materi yang dipelajari, 4) Kelompok kolaboratif bekerja secara bersinergi mengidentifikasi, mendemostrasikan analisis dan memformulasikan jawaban-jawaban tugas atau masalah yang ditemukan sendiri. 5) setelah kelompok kolaboratif menyepakati hasil pemecahan masalah, masingmasing siswa menulis laporan sendiri- sendiri secara lengkap. 6) Guru menunjuk salah satu kelompok secara acak untuk melakukan presentasi hasil diskusi kelompok kolaboratifnya di depan kelas, siswa pada kelompok lain mengamati, mencermati, membandingkan hasil presentasi tersebut, dan menanggapi. Masingmasing siswa dalam kelompok kolaboratif melakukan elaborasi, dan revisi (bila diperlukan) terhadap laporan yang akan dikumpulkan. 7) Laporan masing-masing siswa terhadap tugas-tugas yang telah dikumpulkan, disusun sesuai dengan kelompok kolaboratifnya. 8) Laporan siswa dalam kelompokknya dikoreksi, dikomentari, dinilai, dikembalikan pada pertemuan berikutnya, dan didiskusikan. 9) Memberikan tes diakhir pokok bahasan yang menjadi penutup siklus I.

Tindakan yang dilakukan pada tahap observasi dan penilaian adalah mengamati setiap aktifitas atau kegiatan siswa selama berlangsungnya proses belajar mengajar melalui lembar observasi yang terdiri dari 7 indikator sikap dan kemampuan siswa dalam pembelajaran. Tahap evaluasi dilakukan dengan memberi tes objektif kepada siswa melalui beberapa pertemuan dan bentuk soal pilihan ganda. Dari hasil yang diperoleh pada tahap observasi dan evaluasi, peneliti akan melakukan refleksi. Hasil analisis data yang dilaksanakan dalam tahap (siklus I) ini akan dipergunakan sebagai acuan untuk melaksanakan siklus berikutnya. 


\section{B. Pelaksanaan Siklus II}

Apabila hasil refleksi pada pelaksanaan tindakan siklus I memperlihatkan bahwa pendekatan yang diberikan belum meningkatkan aktivitas belajar siswa, maka perlu dilaksanakan siklus II sebagai kelanjutan, penyempurnaan dari pelaksanaan tindakan siklus I.

Data hasil observasi yang dikumpulkan ada dua macam, yaitu data kualitatif berupa aktifitas siswa selama proses pembelajaran dan data kuantitatif berupa hasil belajar siswa. Data yang terkumpul dianalisis dengan menggunakan analisis statistik deskriptif dan kuantitatif. Data tentang hasil pengamatan (lembar observasi) dianalisis secara kualitatif, sedangkan data tentang hasil belajar siswa dianalisis secara kuantitatif dengan menggunakan statistik deskriptif.

Data mengenai peningkatan ketuntasan hasil belajar siswa SMA Negeri 3 Watampone pada tahun Pelajaran 2016/2017 dapat dilihat pada Tabel 1.

Tabel 1. Kriteria ketuntasan belajar siswa SMA Negeri 3 Watampone.

\begin{tabular}{cc}
\hline Skor & Kategori \\
\hline $0-69$ & Tidak tuntas \\
\hline $70-100$ & Tuntas \\
\hline Sesuai & dengan tujuan
\end{tabular}

penelitian yaitu untuk meningkatkan hasil belajar kimia yang maksimal maka diadakan penelitian tindakan yang berorientasi pada pembelajaran kolaboratif. Untuk mengukur keberhasilan tersebut digunakan skor ketercapaian dan nilai rata-rata kelas dengan syarat ketuntasan individu harus mencapai $70 \%$.

\section{HASIL DAN PEMBAHASAN}

\section{A. Hasil Penelitian Siklus I}

Penelitian tindakan kelas ini terdiri dari dua siklus, setiap satu siklus diwali dengan perencanaan, melakukan tindakan, observasi, evalusi, dan refleksi. Hasil observasi siklus I aktifitas siswa dapat dilihat pada Tabel 2.

Tabel 2. Aktivitas Siswa Berdasarkan Observasi Siklus I

\begin{tabular}{|c|c|c|c|c|c|}
\hline \multirow[t]{2}{*}{ No } & \multirow{2}{*}{$\begin{array}{c}\text { Aktivitas Siswa } \\
\text { Selama } \\
\text { Pembelajaran }\end{array}$} & \multicolumn{3}{|c|}{$\begin{array}{c}\text { Pertemuan } \\
\text { ke- }\end{array}$} & \multirow{2}{*}{$\begin{array}{c}\text { Rata- } \\
\text { rata } \\
(\%)\end{array}$} \\
\hline & & I & II & III & \\
\hline 1 & $\begin{array}{l}\text { Siswa yang } \\
\text { hadir dalam } \\
\text { mengikuti } \\
\text { proses } \\
\text { pembelajaran }\end{array}$ & 24 & 25 & 26 & 83,33 \\
\hline
\end{tabular}

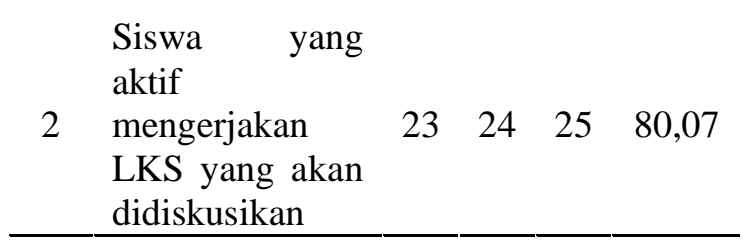

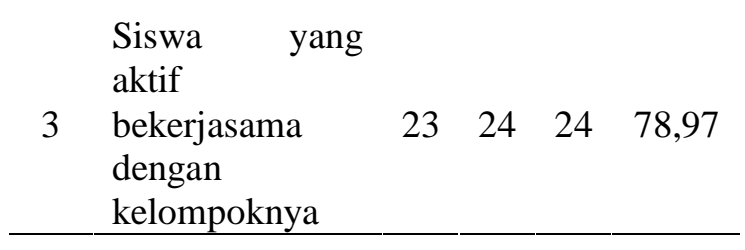

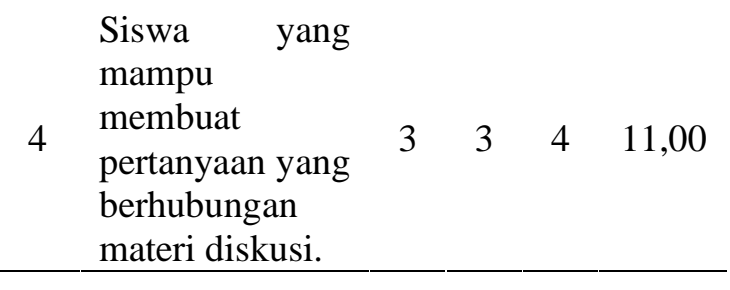

\begin{tabular}{lllllll}
5 & Siswa & yang & 2 & 3 & 3 & 8,89 \\
\hline
\end{tabular}




\begin{tabular}{|c|c|c|c|c|c|}
\hline & $\begin{array}{l}\text { mampu } \\
\text { menjawab } \\
\text { pertanyaan } \\
\text { yang diberikan } \\
\text { oleh kelompok } \\
\text { lain }\end{array}$ & & & & \\
\hline 6 & $\begin{array}{l}\text { Siswa yang } \\
\text { kreatif dalam } \\
\text { memberikan } \\
\text { jawaban kepada } \\
\text { kelompok yang } \\
\text { bertanya. }\end{array}$ & 1 & 2 & 3 & 6,67 \\
\hline 7 & $\begin{array}{l}\text { Siswa yang } \\
\text { disiplin dalam } \\
\text { proses } \\
\text { pembelajaran }\end{array}$ & 23 & 24 & 25 & 80,07 \\
\hline
\end{tabular}

Data observasi di atas dapat dilihat aktivitas siswa selama mengikuti pembelajaran selama tiga kali pertemuan dengan rata-rata $83,33 \%$. Siswa yang aktif mengerjakan LKS yang akan didiskusikan sebesar $80,07 \%$ dan siswa lainnya melakukan aktifitas diluar instruksi dari guru seperti berbicara sesama temannya, mengerjakan tugas mata pelajaran lain.

Siswa yang aktif bekerjasama kelompok kolaboratifnya sebesar $78,97 \%$, adapun siswa yang tidak melakukan kerjasama dalam proses pembelajaran sebesar 21,03\%. Siswa yang mampu membuat pertanyaan berhubungan dengan materi diskusi hanya mencapai $11,00 \%$ dan siswa yang mampu menjawab pertanyaan yang diberikan oleh kelompok lain sebesar $8,89 \%$. Siswa yang memiliki sikap kreatif dalam memberikan jawaban kepada kelompok yang bertanya hanya mencapai $6,67 \%$.
Siswa yang disiplin (mengikuti intruksi dari guru) selama proses pembelajaran mencapai $80,07 \%$.

Berdasarkan hasil observasi siklus I, guru harus tetap berupaya mempertahankan dan meningkatkan semangat belajar siswa dengan melaksanakan semua langkah-langkah pembelajaran kolaboratif sehingga aktivitas dan hasil belajar siswa lebih meningkat.

Tingkat keaktifan guru dalam proses pembelajaran pada siklus I dapat dilihat pada Tabel 3.

Tabel 3. Distribusi indikator observasi aktivitas guru pada siklus I

\begin{tabular}{|c|c|c|c|c|}
\hline \multirow{2}{*}{ No } & \multirow{2}{*}{$\begin{array}{l}\text { Aktivitas guru } \\
\text { selama } \\
\text { pembelajaran }\end{array}$} & \multicolumn{3}{|c|}{ Pertemuan } \\
\hline & & I & II & III \\
\hline 1 & $\begin{array}{l}\text { Menjelaskan skenario } \\
\text { pembelajaran }\end{array}$ & 4 & 4 & 4 \\
\hline 2 & $\begin{array}{lr}\text { Sikap guru terhadap } \\
\text { setiap } & \text { kelompok } \\
\text { kolaboratif }\end{array}$ & 3 & 4 & 4 \\
\hline 3 & $\begin{array}{lr}\text { Perhatian } & \text { yang } \\
\text { diberikan } & \text { kepada } \\
\text { kelompok } & \text { yang } \\
\text { kurang aktif. } & \end{array}$ & 3 & 3 & 4 \\
\hline 4 & $\begin{array}{l}\text { Melengkapi jawaban } \\
\text { dari kelompok diskusi } \\
\text { diakhir pertemuan }\end{array}$ & 3 & 4 & 3 \\
\hline$\overline{\text { Keter }}$ & angan: & & & \\
\hline $\begin{array}{l}\text { Kuali } \\
\text { Kuali } \\
\text { Kuali } \\
\text { Kuali } \\
\text { Kuali }\end{array}$ & $\begin{aligned} \operatorname{tas} 5 & =\text { sangat baik } \\
\operatorname{tas} 4 & =\text { baik } \\
\operatorname{tas} 3 & =\text { cukup } \\
\operatorname{tas} 2 & =\text { kurang } \\
\operatorname{tas} 1 & =\text { tidak terlaksana }\end{aligned}$ & & & \\
\hline
\end{tabular}


Data observasi pada Tabel 3, aktivitas guru pada proses pembelajaran umumnya sampai pada kategori baik. Hasil yang diperoleh masih perlu ditingkatkan yaitu aktivitas guru dalam memperhatikan siswa yang kurang aktif di dalam kelompoknya dan aktivitas guru dalam melengkapai jawaban pertanyaan diskusi diakhir pertemuan karna waktu yang tidak memungkinkan, hal ini berada pada kategori cukup.

Hasil belajar siswa siklus I diukur dari tes evaluasi yang diberikan setelah menyelesaikan empat sub materi dalam sistem koloid, yaitu mengelompokkan campuran yang ada di lingkungan ke dalam suspensi kasar, sistem koloid, 8 macam sistem koloid berdasarkan fase terdispersi dan medium pendispersi, penggunaan sistem koloid (bidang industri, kosmetik, makanan, farmasi dll) serta sifat-sifat koloid. Hasil analisis deskriptif dengan skor siswa yang diperoleh setelah menerapkan metode pembelajaran kolaboratif menunjukkan bahwa skor rata-rata siswa dalam kelas adalah 60,50 dari skor ideal yaitu 100 dengan jumlah 30 siswa. Skor tertinggi yang diperoleh pada siklus I yaitu 80,00 dan skor terendah yaitu 25,00.

Persentase ketuntasan belajar kimia siswa setelah menggunakan penerapan metode pembelajaran kolaboratif pada siklus I dapat dilihat pada tabel 4.
Tabel 4. Deskriptif Ketuntasan belajar Siswa Pada Siklus I

\begin{tabular}{cccc}
\hline Skor & Kategori & Frekuensi & $\begin{array}{c}\text { Persentase } \\
(\%)\end{array}$ \\
\hline$<70$ & $\begin{array}{c}\text { Tidak } \\
\text { tuntas }\end{array}$ & 14 & 46,67 \\
\hline$\geq 70$ & Tuntas & 14 & 46,67 \\
\hline $\begin{array}{c}\text { Siswa yang tidak } \\
\text { ikut tes }\end{array}$ & 2 & 6,66 \\
\hline
\end{tabular}

Pada tabel 4 di atas tampak bahwa dari 30 siswa yang berhasil dalam kategori tuntas hanya berjumlah $14(46,67 \%)$ orang dan $14(46,67 \%)$ siswa dikategorikan tidak tuntas. Siswa yang tidak ikut tes pada siklus I yaitu berjumlah $2(6,66 \%)$ orang. Berdasarkan data tersebut di atas bahwa siswa yang tuntas dengan nilai hasil belajarnya hampir sama (akibat adanya siswa yang tidak ikut tes) dengan siswa yang tidak tuntas.

Hasil refleksi pada siklus I, terdapat beberapa kekurangan pada proses belajar mengajar dengan menggunakan metode pembelajaran kolaboratif yang akan ditindaklanjuti pada siklus II. Adapun hasil refleksi siklus I adalah sebagai berikut: 1) Tiap kelompok belum menunjukkan kerjasama yang baik pada saat mengerjakan LKS, disebabkan dengan pembagian kelompok secara heterogen sehingga ada beberapa siswa belum terbiasa dengan kelompok kolaboratifnya yang baru. 2) Beberapa siswa tidak percaya diri akan kemampuan yang dimilikinya, masih bergantung kepada teman kelompoknya yang menonjol (berprestasi). Ketidakaktifan sebagian siswa disebabkan dengan jumlah tiap 
kelompok terlalu banyak yaitu 5 orang sehingga hanya dua atau tiga orang yang aktif dikelompoknya. 3) Minimnya buku pegangan yang dimiliki oleh siswa sehingga mengalami kendala dalam menjawab pertanyaan LKS.

Berbagai kendala yang terjadi pada siklus I, maka sebagai refleksi dilakukan perbaikan pada pelaksanaan siklus II diantaranya: 1) Peneliti tetap membentuk kelompok secara heterogen berdasarkan hasil tes siklus I dengan mereduksi jumlah siswa dalam tiap kelompok yaitu dari lima menjadi tiga orang. Hal ini dilakukan karna melihat pelaksanaan siklus I tidak efektif dalam bekerjasama dengan kelompoknya. Pembentuk kelompok baru ini berdasarkan pertimbangan yaitu melihat siswa yang aktif dan tidak aktif pada kelompok sebelumnya. 2) Memotivasi siswa dengan cara memberikan pujian dan semangat yang tinggi sehingga siswa yang awalnya tidak percaya akan potensi yang dimilikinya menjadi lebih giat dan berusaha menampakkan kebolehannya kepada teman kelompok yang lainnya, dengan demikian prestasi siswa akan meningkat dibandingkan sebelumnya (siklus I).

Berdasarkan hasil penelitian pada siklus I, maka hipotesis dalam penelitian siklus II adalah: "Jika dalam proses belajar mengajar kimia menggunakan metode pembelajaran kolaboratif dengan menerapkan langkah-langkah sebagai berikut: 1) membagi kelompok siswa terdiri dari tiga orang, dilakukan secara heterogen berdasarkan nilai ketuntasan siswa setelah diadakan tes siklus I, selanjutnya memberikan kesempatan kepada masing-masing kelompok untuk berdiskusi, saling tukar pikiran memberikan informasi dalam mengerjakan LKS yang telah dibagikan, 2) memberikan kesempatan kepada tiap kelompok untuk bersiapsiap mempersentasekan hasil diskusinya dengan teman kelompoknya dengan mengacak/mencabut lot yang telah disediakan. Bagi siswa yang muncul nomor kelompoknya bersedia ke depan kelas untuk membacakan jawabannya dan siswa pada tiap kelompok menanggapi dan menanyakan hal-hal yang dianggap belum dimengerti dari materi yang didiskusikan, maka dengan demikian hasil belajar siswa akan meningkat.

\section{B. Hasil Penelitian Siklus II}

Observasi pada siklus II ini masih sama dengan siklus I, setiap aktivitas yang terdapat dalam metode pembelajaran kolaboratif pada umumnya telah memperlihatkan peningkatan keaktifan siswa dalam proses belajar jika dibandingkan dengan siklus I.

Tabel 5. Aktivitas Siswa Berdasarkan Data Observasi Pada Siklus II

\begin{tabular}{|c|c|c|c|c|}
\hline \multirow[t]{2}{*}{ No } & \multirow{2}{*}{$\begin{array}{c}\text { Aktivitas } \\
\text { Siswa Selama } \\
\text { Pembelajaran }\end{array}$} & \multicolumn{2}{|c|}{$\begin{array}{c}\text { Pertemuan } \\
\text { ke- }\end{array}$} & \multirow{2}{*}{$\begin{array}{c}\text { Rata- } \\
\text { rata } \\
(\%)\end{array}$} \\
\hline & & I & II & \\
\hline 1 & $\begin{array}{l}\text { Siswa yang } \\
\text { hadir dalam } \\
\text { mengikuti } \\
\text { proses } \\
\text { pembelajaran }\end{array}$ & 25 & 26 & 85,00 \\
\hline
\end{tabular}




\begin{tabular}{|c|c|c|c|c|}
\hline 2 & $\begin{array}{l}\text { Siswa yang } \\
\text { aktif } \\
\text { mengerjakan } \\
\text { LKS yang akan } \\
\text { didiskusikan. }\end{array}$ & 24 & 26 & 83,33 \\
\hline 3 & $\begin{array}{l}\text { Siswa yang } \\
\text { aktif } \\
\text { bekerjasama } \\
\text { dengan } \\
\text { kelompoknya }\end{array}$ & 24 & 26 & 83,33 \\
\hline 4 & $\begin{array}{l}\text { Siswa yang } \\
\text { mampu } \\
\text { membuat } \\
\text { pertanyaan } \\
\text { yang } \\
\text { berhubungan } \\
\text { dengan materi } \\
\text { diskusi. }\end{array}$ & 4 & 5 & 15,00 \\
\hline 5 & $\begin{array}{l}\text { Siswa yang } \\
\text { mampu } \\
\text { menjawab } \\
\text { pertanyaan } \\
\text { yang diberikan } \\
\text { oleh kelompok } \\
\text { lain. }\end{array}$ & 3 & 4 & 11,66 \\
\hline 6 & $\begin{array}{l}\text { Siswa yang } \\
\text { kreatif dalam } \\
\text { memberikan } \\
\text { jawaban kepada } \\
\text { kelompok yang } \\
\text { bertanya } \\
\end{array}$ & 2 & 3 & 8,33 \\
\hline 7 & $\begin{array}{l}\text { Siswa yang } \\
\text { disiplin dalam } \\
\text { proses } \\
\text { pembelajaran }\end{array}$ & 24 & 26 & 83,33 \\
\hline
\end{tabular}

Berdasarkan data observasi di atas dapat dilihat aktivitas siswa selama mengikuti pembelajaran selama dua kali pertemuan dengan rata-rata $85,00 \%$. Siswa yang aktif mengerjakan LKS yang akan didiskusikan mencapai 83,33\%.
Siswa yang aktif bekerjasama kelompok kolaboratifnya sebesar $83,33 \%$, Siswa yang mampu membuat pertanyaan berhubungan dengan materi diskusi hanya mencapai $15,00 \%$ dan siswa yang mampu menjawab pertanyaan yang diberikan oleh kelompok lain sebesar $11,66 \%$. Siswa yang memiliki sikap kreatif dalam memberikan jawaban kepada kelompok yang bertanya hanya mencapai $8,33 \%$. Siswa yang disiplin (mengikuti intruksi dari guru) selama proses pembelajaran mencapai $83,33 \%$.

Hasil observasi aktivitas guru pada siklus II selama pembelajaran mengalami sedikit peningkatan, hal ini dapat dilihat pada tabel 6 dimana guru mampu mengarahkan siswa kepada konsep pembelajaran kolaboratif yang sebenarnya. Siswa yang telah di kelompokkan berdasarkan hasil belajarnya sudah mampu memahami akan maksud dari pembelajaran yang diberikan dimana hampir semuanya berada pada kategori baik, dengan demikian aktivitas guru selama pembelajaran pada siklus II mengalami peningkatan.

Tabel 6. Distribusi indikator observasi aktivitas guru pada siklus II

\begin{tabular}{lllc}
\hline No & $\begin{array}{l}\text { Aktivitas guru } \\
\text { selama proses } \\
\text { pembelajaran }\end{array}$ & \multicolumn{2}{c}{ Pertemuan } \\
\cline { 3 - 4 } & $\begin{array}{l}\text { Menjelaskan } \\
\text { skenario } \\
\text { pembelajaran }\end{array}$ & II \\
\hline 2 & $\begin{array}{l}\text { Sikap guru terhadap } \\
\text { setiap kelompok }\end{array}$ & 4 & 4 \\
\hline
\end{tabular}




\begin{tabular}{llll}
\hline kolaboratif & & \\
\hline 3 & $\begin{array}{l}\text { Perhatian yang } \\
\text { diberikan guuru } \\
\text { kepada kelompok } \\
\text { yang kuarang aktif }\end{array}$ & 4 & 4 \\
\hline 4 & $\begin{array}{l}\text { Melengkapi jawaban } \\
\text { dari kelompok } \\
\text { diskusi diakhir } \\
\text { pertemuan }\end{array}$ & 3 & 4 \\
\hline
\end{tabular}

Hasil analisis deskriptif tes hasil belajar kimia siswa pada siklus II menunjukkan bahwa skor rata-rata siswa dalam kelas adalah $72,33 \%$ dari skor ideal yaitu $100 \%$ dengan jumlah 30 siswa. Skor tertinggi yang diperoleh pada siklus II yaitu 90,00 dan skor terendah yaitu 65,00 .

Persentase ketuntasan belajar kimia siswa setelah menggunakan penerapan metode pembelajaran kolaboratif pada siklus II dapat dilihat pada Tabel 7.

Tabel 7. Deskriptif Ketuntasan belajar Siswa Pada Siklus II

\section{Skor Kategori Frekuensi Persentase}

(\%)

\begin{tabular}{|c|c|c|c|}
\hline$<70$ & $\begin{array}{l}\text { Tidak } \\
\text { tuntas }\end{array}$ & 2 & 6,67 \\
\hline$\geq 70$ & Tuntas & 26 & 86,66 \\
\hline \multicolumn{2}{|c|}{$\begin{array}{c}\text { Siswa yang tidak } \\
\text { ikut tes }\end{array}$} & 2 & 6,67 \\
\hline \multicolumn{2}{|c|}{ Jumlah } & 30 & 100 \\
\hline
\end{tabular}

Pada tabel 7 di atas tampak bahwa dari 30 siswa yang berhasil dalam kategori tuntas hanya berjumlah $26(86,66 \%)$ orang dan $2(6,67 \%)$ siswa dikategorikan tidak tuntas. Siswa yang tidak ikut tes pada siklus II yaitu berjumlah $2(6,67 \%)$ orang. Berdasarkan data tersebut di atas, siswa yang tuntas dengan nilai hasil belajarnya mengalami banyak peningkatan jika dibandingkan dengan siswa yang tidak tuntas.

Hasil refleksi pada siklus II, masih terdapat beberapa kekurangan pada proses belajar mengajar dengan menggunakan metode pembelajaran kolaboratif yang akan ditindaklanjuti pada siklus II. Adapun kekurangan tersebut adalah sebagai berikut: 1) Keterlibatan siswa dalam bekerjasama dengan kelompoknya masih rendah, terkadang masih membutuhkan jawaban dari kelompok lain dalam menyelesaikan LKS. Ketidakpercayaan diri masih melekat pada diri siswa dan kurangnya buku pegangan yang dimiliki. 2) Ketidakmampuan siswa dalam memberikan suatu pertanyaan kepada kelompok diskusi sehingga yang hanya beberapa siswa saja yang aktif dalam mengajukan suatu pertanyaan yang berhubungan dengan materi diskusi.

Berdasarkan hasil penelitian "Penerapan Metode pembelajaran Kolaboratif pada Materi Koloid Siswa Kelas XI IPA1 SMA Negeri 3 Watampone" mengalami perubahan yang signifikan pada hasil observasi dan hasil belajar siswa antara siklus siklus I dengan siklus II. Perbedaan tersebut dapat dilihat pada Tabel 8. 
Tabel 8. Perbedaan hasil observasi dan hasil belajar pada siklus I dan II

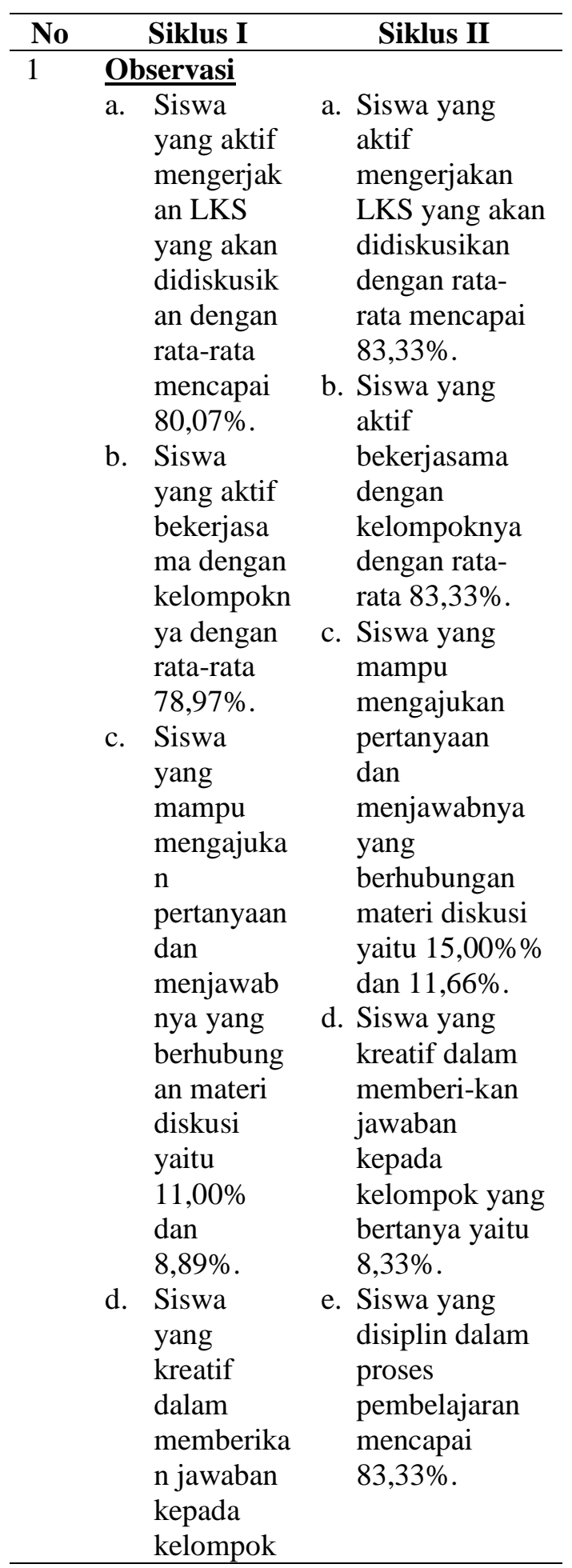

\begin{tabular}{|c|c|c|c|}
\hline & e. & $\begin{array}{l}\text { yang } \\
\text { bertanya } \\
\text { yaitu } \\
6,67 \% \text {. } \\
\text { Siswa } \\
\text { yang } \\
\text { disiplin } \\
\text { dalam } \\
\text { proses } \\
\text { pembelajar } \\
\text { an } \\
\text { mencapai } \\
80,07 \% \text {. }\end{array}$ & \\
\hline 2 & $\underline{\mathrm{H}}$ & $\begin{array}{l}\text { sil belajar } \\
\text { Hasil tes } \\
\text { siswa } \\
\text { belajar } \\
\text { siswa pada } \\
\text { siklus I } \\
\text { dengan } \\
\text { skor rata- } \\
\text { rata } 60,50 \text {. } \\
\text { Pengkatego } \\
\text { rian pada } \\
\text { tingkat } \\
\text { ketuntasan } \\
\text { belajar } \\
\text { siswa yang } \\
\text { memperole } \\
\text { h skor } 70 \\
\text { keatas } \\
\text { sebanyak } \\
14 \\
\text { (46,67\%) } \\
\text { dari } 30 \\
\text { siswa }\end{array}$ & $\begin{array}{l}\text { a. Hasil tes siswa } \\
\text { belajar siswa } \\
\text { pada siklus II } \\
\text { dengan skor } \\
\text { rata-rata } 72,33 \text {. } \\
\text { b. Pengkategorian } \\
\text { pada tingkat } \\
\text { ketuntasan } \\
\text { belajar siswa } \\
\text { yang } \\
\text { memperoleh } \\
\text { skor } 70 \text { keatas } \\
\text { sebanyak 26 } \\
\text { (86,66\%) dari } \\
30 \text { siswa }\end{array}$ \\
\hline
\end{tabular}

Hasil observasi pada siklus I dan siklus II, terdapat beberapa peningkatan yang terjadi diantaranya siswa yang aktif mengerjakan LKS yang akan didiskusikan dalam kelompoknya dari $80,07 \%$ menjadi 83,33\%. Setelah memperbaiki kekurangan pada siklus I dengan 
mengurangi jumlah siswa setiap kelompok dari lima menjadi tiga orang, terjadi perubahan dan peningkatan dimana siswa menjadi lebih aktif dalam menjawab setiap pertanyaan LKS dengan menggunakan buku pegangan dan penunjang lainnya.

Siswa yang aktif bekerjasama dengan kelompoknya juga mengalami peningkatan yang ditandai dengan persentase rata-rata yaitu $78,97 \%$ menjadi $83,33 \%$. Pada siklus I masih terdapat kekurangan dalam bekerjasama setiap kelompok, hal ini terjadi karna adanya ketidak cocokan antara siswa yang satu dengan lainnya sehingga hanya beberapa siswa saja yang aktif bekerja (menyelesaikan tugas yang diberikan). Setelah diadakan perbaikan pada siklus II terjadi peningkatan kerjasama diantara siswa dalam kelompoknya, hal ini terlihat dengan waktu yang telah ditetapkan semua pertanyaan LKS dijawab dengan baik.

Siswa yang mampu membuat pertanyaan yang berhubungan materi diskusi mengalami peningkatan yang terjadi pada siklus II, terlihat banyaknya siswa yang mengajukan pertanyaan kepada kelompok yang mempersentasekan jawaban LKS yang diberikan, dari $11,00 \%$ menjadi $15,00 \%$. Adapun siswa yang mampu menjawab pertanyaan yang diberikan oleh kelompok lain juga mengalami peningkatan pada siklus II setelah diberikan motivasi maka siswa yang awalnya marasa ragu (takut salah) akhirnya berusaha menjawab dari pertanyaan kelompok lain, hal ini terlihat dari persentase yang dicapai yaitu $8,89 \%$ menjadi $11,66 \%$.
Siswa yang kreatif dalam memberikan jawaban kepada kelompok yang bertanya juga mengalami sedikit peningkatan, dengan pengetahuan yang dimiliki sebagian dari siswa masih minim dalam hal pengelolaan bahasa yang mengarah kepada jawaban dari pertanyaan yang diajukan sehingga masih banyak siswa yang jawabannya kurang lebih sama dengan apa yang ada di buku. Walaupun demikian, masih ada diantara siswa yang mampu menjawab dengan ide kreatif sehingga terjadi peningkatan dari $6,67 \%$ menjadi $8,33 \%$.

Siswa yang disiplin dalam proses pembelajaran sangat diharapkan dalam kelangsungan pembelajaran sehingga sesuatu yang disampaikan kepada siswa dapat diterima dengan baik dan waktu yang digunakan dapat termanfaatkan dengan baik pula dalam kegiatan pembelajaran. Setelah melihat hasil observasi pada sikluis I dan siklus II terjadi peningkatan yaitu $80,07 \%$ menjadi $83,33 \%$.

Hasil penelitian menunjukkan bahwa ada peningkatan hasil belajar siswa dan peningkatan aktivitas serta perubahan sikap siswa kelas XI IPA1 SMA Negeri 3 Watampone setelah menerapkan metode pembelajaran kolaboratif, dilihat dari tes hasil belajar siswa dan lembar observasi. Peningkatan hasil belajar dapat dilihat pada rata-rata hasil belajar siswa, dimana pada siklus I skor rata-rata yang diperoleh siswa adalah 60,50 dan pada siklus II dengan skor rata-rata yang diperoleh siswa adalah 72,33. Berdasarkan tabel pengkategorian tingkat ketuntasan belajar siswa pada 
siklus I dapat dilihat bahwa siswa yang memperoleh skor 70 ke atas (tuntas) sebanyak $14(46,67 \%)$ orang dari 30 siswa. Sedangkan siklus II yang memperoleh skor 70 keatas sebanyak $26(86,66 \%)$.

Berdasarkan hasil observasi pada saat melakukan penelitian yaitu pada siklus I dan siklus II, terjadi beberapa perubahan dengan adanya peningkatan aktivitas serta perubahan pada diri siswa. Mengacu pada observasi yang telah dilakukan selama penelitian serta perubahan-perubahan tindakan yang telah dilakukan, ternyata dapat mempengaruhi hasil belajar siswa sehingga mengalami peningkatan hasil belajar pada siklus II, dengan demikian penggunaan metode pembelajaran kolaboratif menjadi lebih baik dari sebelumnya.

\section{KESIMPULAN DAN SARAN}

\section{A. Kesimpulan}

Berdasarkan hasil analisis data dan pembahasan, maka dapat ditarik beberapa kesimpulan yaitu dengan menggunakan metode pembelajaran kolaboratif ternyata cukup baik apabila diterapkan pada materi pokok sistem koloid dalam upaya meningkatkan keaktifan siswa kelas XI IPA1 SMA Negeri 3 Watampone, dengan langkah-langkah sebagai berikut: 1) membangi siswa dalam beberapa kelompok berdasarkan hasil belajar siswa, 2) membagikan LKS kepada setiap kelompok untuk menjawab pertanyaan dengan saling tukar pikiran menyumbangkan informasi/jawaban sehingga terjadi kerjasama yang baik, 3) memberikan kesempatan kepada setiap kelompok untuk mempersentasikan jawabannya dengan cara mengacak/mencabut lot yang dilakukan oleh perwakilan dari kelompok lain, 4) kelompok lain membandingan jawaban kelompoknya, menanggapi dan mengajukan pertanyaan atau tanggapan kepada kelompok yang mempersentasikan jawabannya.

\section{B. Saran}

Peningkatan hasil belajar menjadi harapan dari setiap peneliti, maka ada yang menjadi saran adalah penerapan metode pembelajaran kolaboratif yang dilakukan senantiasa memperhatikan kerjasama siswa dalam kelompoknya sehingga tercipta suasana yang menyenangkan dan pengetahuan yang diperoleh siswa akan sama antara yang satu dengan lainnya.

\section{DAFTAR PUSTAKA}

Mulyawan, 2006, Pembelajaran Kolaboratif, PT. Gramedia, Jakarta. Santyasa, Wayan, 2006, Pembelajaran Inovatif, Model Kolaboratif, UPGanesa, Semapara. Sudarman., 2012, Penerapan metode collaborative learning, YSN-KPS Balikpapan, Balikpapan. 